${ }^{29}$ Greenland S, Neutra R. An analysis of detection bias and proposed corrections in the study of estrogens and endometrial cancer. $\mathcal{F}$ Chronic Dis $1981 ; 34: 433-8$.

30 Klatsky AL, Friedman GD, Siegelaub AB. Alcohol use and cardiovascular disease: the Kaiser-Permanente experience. Circulation 1981;64, suppl III :32-41.

31 Thornton J, Symes C, Heaton K. Moderate alcohol intake reduces bile cholesterol saturation and raises HDL cholesterol. Lancet 1983; ;i : 819-22.

32 Nestel PJ, Simons LA, Homma Y. Effects of ethanol on bile acid and cholesterol metabolism. Am F Clin Nutr 1976;29:1007-15.

33 Topping DL, Weller RA, Nader CJ, et al. Adaptive effects of dietary ethanol in the pig: changes in plasma high-density lipoproteins and fecal steroid excretion and mutagenicity. Am $\mathcal{f}$ Clin Nutr 1982;36: 245-50.

34 Yoshida T, McCormick WC, Swell L, Vlahcevic ZR. Bile acid metabolism in cirrhosis. IV. Characterization of the abnormality in deoxycholic acid metabolism. Gastroenterology 1975;68:335-41.

35 Williams CN, Scallion SM, McCarthy SC. A diet containing highly refined carbohydrate will adversely change bile lipid composition to that seen in cholesterol gallstone disease. Ann $R$ Coll Phys Surg Canado 1979;12:44.

36 Thornton JR, Emmett PM, Heaton KW. Diet and gall stones: effects of refined and unrefined carbohydrate diets on bile cholesterol saturation and bile acid metabolism. Gut 1983;24:2-6.

37 Dam $\mathrm{H}$, Christensen $\mathrm{F}$. Alimentary production of gallstones in hamsters. Acta Pathol Microbiol Scand 1952;30:236-41.

"Swan DC, Davidson P, Albrink MJ. Effect of simple and complex carbohydrates on plasma non-esterified fatty acids, plasma sugar, and plasma insulin during oral carbohydrate tolerance tests. Lancet 1966; $\mathrm{i}: 60-3$.

${ }^{3 y}$ Wahlqvist ML, Wilmshurst EG, Murton CR, Richardson EN. The effect of chain length on glucose absorption and the related metabolic response. Am f Clin Nutr 1978;31:1998-2001.

11) Crapo PA, Scarlett JA, Kolterman OG. Comparison of the metabolic responses to fructose and sucrose sweetened foods. Am $\mathrm{f}$ Clin Nutr $1982 ; 36: 256-61$.

"Reiser S, Handler HB, Gardner LB, et al. Isocaloric exchange of dietary starch and sucrose in humans. II. Effect on fasting blood insulin, glucose, and glucagon and on insulin and glucose response to a sucrose load. Am 7 Clin Nutr 1979 ;32:2206-16.

12 Reiser S, Bohn E, Hallfrisch J, et al. Serum insulin and glucose in hyperinsulinemic subjects fed three different levels of sucrose. $\mathrm{Am} \mathcal{f} \mathrm{Clin}$ Nutr $1981 ; 34: 2348-58$

${ }^{13}$ Coulston A, Greenfield MS, Kraemer FB, et al. Effect of differences in source of dietary carbohydrate on plasma glucose and insulin responses to meals in patients with impaired carbohydrate tolerance. Am $\mathcal{F}$ Clin Nutr $1981 ; 34: 2716-20$.

" McMichael AJ, Potter JD, Hetzel BS. Time trends in colo-rectal cancer mortality in relation to food and alcohol consumption: United States, United Kingdom, Australia and New Zealand. Int 7 Epidemiol 1979; 8:295-303.

${ }^{15}$ Boston Collaborative Drug Surveillance Programme. Oral contraceptives and venous thromboembolic disease, surgically confirmed gall-bladder disease, and breast tumours. Lancet 1973;i:1399-404.

16 Sarles H, Hauton J, Planche N, Lafont H, Gerolami A. Diet, cholesterol gallstones, and composition of the bile. Am F Dig Dis 1970;15:251-60.

${ }^{17}$ Grundy SM. Effects of polyunsaturated fats on lipid metabolism in patients with hypertriglyceridemia. F Clin Invest 1975;55:269-82.

48 Dam H, Kruse I, Jensen K, Kallehauge HE. Studies on human bile. II. Influence of two different fats on the composition of human bile. Scand $\mathcal{F}$ Clin Lab Invest 1967;19:367-78.

19 Schlierf G, Nikolaus T, Stiehl A, et al. Zur Wirkung lipidspiegelsenkender Kostformen auf Gallenlipide und Plasmalipoproteine bei Normalpersonen. Schweiz Med Wochenschr 1979;109:1743-7.

${ }^{50}$ Dam H, Prange I, Jensen K, et al. Studies on human bile. IV. Influence of ingestion of cholesterol in the form of eggs on the composition of bile in healthy subjects. $Z$ Ernahrungswiss $1971 ; 10: 178-87$.

51 Andersen E, Hellstrom K. The effects of cholesterol feeding on bile acid kinetics and biliary lipids in normolipidemic and hypertriglyceridemic subjects. F Lipid Res 1979;20:1020-7.

52 Pomare EW, Heaton KW, Low-Beer TS, Espiner HJ. The effect of wheat bran upon bile salt metabolism and upon the lipid composition of bile in gallstone patients. Am F Dig Dis 1976;21:521-6.

${ }^{53}$ McDougall RM, Yakymyshyn L, Walker K, Thurston OG. Effect of wheat bran on serum lipoproteins and biliary lipids. Can $\mathcal{F}$ Surg 1978; $21: 433-5$

${ }^{54}$ Watts J McK, Jablonski P, Toouli J. The effect of added bran to the diet on the saturation of bile in people without gallstones. Am F Surg 1978; $135: 321-4$.

${ }^{55}$ Horn G. Observations on the aetiology of cholelithiasis. $\mathrm{Br} \mathrm{Med} \mathcal{F} 1956$; ii:732-7.

${ }^{56}$ Bernstein RA, Werner LH, Rimm AA. Relationship of gallbladder disease to parity, obesity, and age. Health Serv Rep 1973;88:925-36.

${ }^{57}$ Newman $\mathrm{HF}$, Northup JD. The autopsy incidence of gallstones. Int Abstr Surg (issued with Surg Gynecol Obstet) 1959;109:1-13.

${ }^{58}$ Honore LH. Cholesterol cholelithiasis in adolescent females. Its connection with obesity, parity, and oral contraceptive use-a retrospective study of 31 cases. Arch Surg 1980;115:62-4.

\title{
Negative selection of patients for dialysis and transplantation in the United Kingdom
}

\author{
S CHALLAH, A J WING, R BAUER, R W MORRIS, S A SCHROEDER
}

\begin{abstract}
In order to understand why the United Kingdom ranks low in the treatment of end stage renal failure a questionnaire investigating knowledge of current acceptance practice for dialysis and transplantation was sent to various groups of doctors throughout the country. The questionnaire comprised 16 case histories of patients with established end stage renal failure and associated social
\end{abstract}

\section{St Thomas's Hospital, London}

S CHAL.LAH, MB, BCHIR, registrar in community medicine

A J WING, DM, FRCP, consultant physician, chairman, EDTA Registration committee

R BAUER, MD, MSC, Millbank scholar, department of community medicine $R$ W MORRIS, MSC, lecturer in medical statistics, department of community medicine

S A SCHROEDER, MD, visiting professor, department of community medicine

Correspondence to: Dr S Challah, EDTA, St Thomas's Hospital, London SE1 7EH. and medical problems. In each case the responding doctor was asked to indicate whether the patient would be suitable for treatment by dialysis or transplantation or both. The questionnaire was sent to a randomly selected sample of general practitioners and non-renal consultant physicians and their responses compared with those of all the nephrologists identified in the United Kingdom.

The mean number of cases rejected by both general practitioners and non-renal consultant physicians was significantly higher than the number rejected by nephrologists. The findings suggest that underreferral of patients to dialysis and transplant units contributes to the current low acceptance rate of new patients into treatment programmes in the United Kingdom.

\section{Introduction}

The United Kingdom ranks low in the treatment of end stage renal failure by dialysis and transplantation (see table I). In 1981 only 26.7 new patients per million population were accepted into 
TABLE I-Crude acceptance rates (per million population) of new patients for renal replacement therapy in 23 European countries during $1981^{1}$

\begin{tabular}{|c|c|c|c|}
\hline \multicolumn{3}{|c|}{$\begin{array}{c}\text { Acceptance } \\
\text { rate }\end{array}$} & $\begin{array}{c}\text { Acceptance } \\
\text { rate }\end{array}$ \\
\hline $\begin{array}{l}\text { Sweden } \\
\text { Federal Republic of Germany } \\
\text { Norway } \\
\text { Belgium } \\
\text { Israel } \\
\text { Switzerland } \\
\text { Italy } \\
\text { France } \\
\text { Austria } \\
\text { Denmark } \\
\text { Finland } \\
\text { Spain }\end{array}$ & $\begin{array}{l}51 \cdot 3 \\
49 \cdot 7 \\
48 \cdot 5 \\
48 \cdot 4 \\
48 \cdot 4 \\
45 \cdot 1 \\
43 \cdot 1 \\
42 \cdot 3 \\
40 \cdot 5 \\
37 \cdot 1 \\
36 \cdot 7 \\
36 \cdot 7\end{array}$ & $\begin{array}{l}\text { Netherlands } \\
\text { Luxembourg } \\
\text { Greece } \\
\text { Scotland } \\
\text { England } \\
\text { Eire } \\
\text { Iceland } \\
\text { Northern Ireland } \\
\text { Yugoslavia } \\
\text { Democratic Republic of } \\
\text { Germany } \\
\text { Wales }\end{array}$ & $\begin{array}{l}34 \cdot 8 \\
32.5 \\
31 \cdot 6 \\
28.7 \\
25 \cdot 4 \\
25 \cdot 2 \\
25.0 \\
23.3 \\
23 \cdot 2\end{array}$ \\
\hline
\end{tabular}

treatment programmes in this country as compared with 42.3 in France, 43.1 in Italy, 49.7 in the Federal Republic of Germany, and over 60 in the United States.

The failure to treat in the United Kingdom is most striking among those aged 45 and over and is usually attributed to underprovision of renal replacement services. Nephrologists claim, however, that they are not turning large numbers of patients away.

The incidence of end stage renal failure appears to be similar in Western countries. ${ }^{2-4}$ Other factors that might contribute to the shortfall in treatment include underdiagnosis and underreferral to renal units. The high age specific acceptance rate of young patients into dialysis and transplantation programmes in the United Kingdom is comparable to that in France, the Federal Republic of Germany, and Italy (see fig 1) and shows that there is an effective system for detecting end stage renal failure in this country. The present study was set up to investigate the question of underreferral.

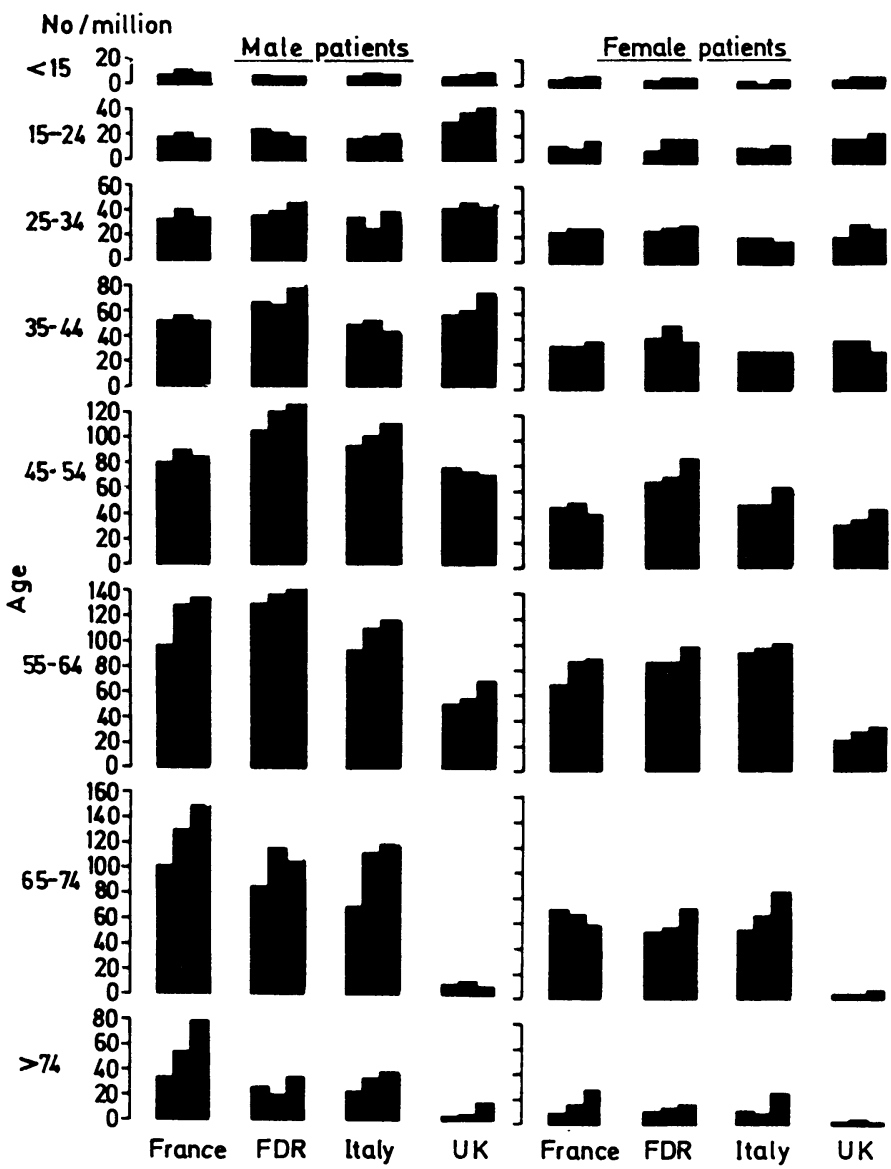

FIG 1-Age and sex specific acceptance rates (per million population) of new patients for renal replacement therapy in France, Federal Republic of Germany (FDR), Italy, and the United Kingdom during 1979-81. (Reproduced from Challah and Wing ${ }^{10}$ with the editors' permission.)
Figure 2 shows the usual referral chain for a patient developing chronic renal failure in Britain. Initial presentation is usually to a general practitioner; diagnosis at this stage may result in referral to a renal unit if there is one accessible, but a more usual step is referral to a local consultant physician, who may then send the patient to a nephrologist for an opinion. In this study a questionnaire was used to investigate knowledge of current acceptance practice for dialysis and transplantation among a wide cross section of doctors in the United Kingdom at all points in the referral chain.

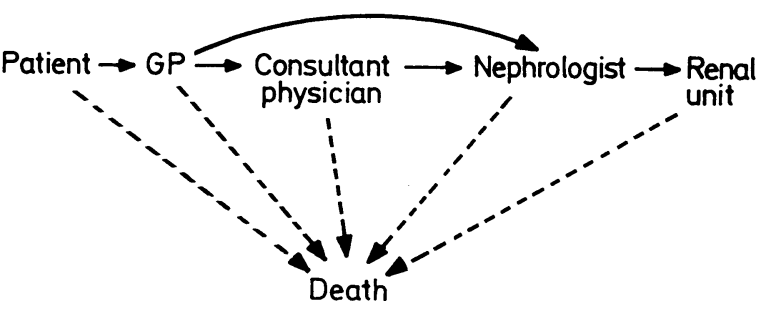

FIG 2-Referral pathway for patient developing chronic renal failure in United Kingdom.

\section{Methods}

A total of 708 doctors were contacted, comprising 297 consultant physicians, 306 general practitioners, and 105 nephrologists. The sample of consultant physicians, who included specialists in general medicine, cardiology, chest disease, rheumatology, and geriatrics, was drawn at random from lists provided by each health authority in the United Kingdom. In the few cases where an authority declined to provide the names and addresses of consultants by specialty the listing in the Medical Directory was used. The 306 general practitioners were taken from the lists provided by a random sample of 30 out of 113 family practitioner committees or their equivalent in the United Kingdom. All 105 nephrologists identified by the United Kingdom Transplant Service were also included in the sample.

Each doctor was sent a questionnaire and a covering letter. The questionnaire contained 16 case histories of subjects with established end stage renal failure and the doctor was asked to make a yes or no decision for each patient on whether treatment by dialysis or transplantation or both would be appropriate, bearing in mind local renal services. It was stated that the patients were not in competition with one another for facilities. Each of the histories was brief and based on fact; all of the patients had associated social or medical problems that might militate against acceptance for treatment. (Copies of the questionnaire are available on request.)

The mean values of the number of cases rejected by each type of doctor were compared by unpaired $t$ tests, as the distribution approximated that of a normal curve. For the same reason linear regression analyses were carried out to investigate simultaneously the effects of level of provision of services, as defined by regional acceptance rates for dialysis and transplantation in $1981,{ }^{5}$ and year of graduation of the doctors.

In order to make further comparisons the questionnaire was also sent to selected nephrologists in Europe and North America, who in turn were asked to circulate it among their general medical colleagues.

\section{Results}

Response rates were high $(69.4 \%$ overall), ranging from $62.0 \%$ of cunsultant physicians to $86.7 \%$ of nephrologists (table II). There was no significant difference between respondents and non-respondents in year of graduation or regional provision level of renal services.

Figure 3 shows the mean number of cases rejected (out of 16) by each of the three groups of doctors. A significantly higher $(p<0.001)$ number of patients was rejected by both consultant physicians and general practitioners $(7.4(\mathrm{SD} 0.2)$ and 6.9 (SD 0.3) respectively) than by nephrologists $(4 \cdot 7(\operatorname{SD} 0 \cdot 3))$. Rejection rates for individual cases varied from $8.4 \%$ for a 55 year old Jamaican woman with asthma to $83.9 \%$ for a 52 year old alcoholic man living in a hostel. Table III lists the rejection rates by case and type of doctor. The ranking of cases is shown in parentheses as 1 to 16,1 being most likely to be accepted for treatment and 16 least likely. 
TABLE II-Percentage response rates to questionnaire by type of doctor. (Numbers of doctors approached in each group given in parentheses)

\begin{tabular}{lcccc}
\hline & Nephrologists & $\begin{array}{c}\text { General } \\
\text { practitioners }\end{array}$ & $\begin{array}{c}\text { Consultant } \\
\text { physicians }\end{array}$ & All \\
\hline$\%$ Response & $86.7(105)$ & $70.6(306)$ & $62.0(297)$ & $69.4(708)$ \\
\hline
\end{tabular}

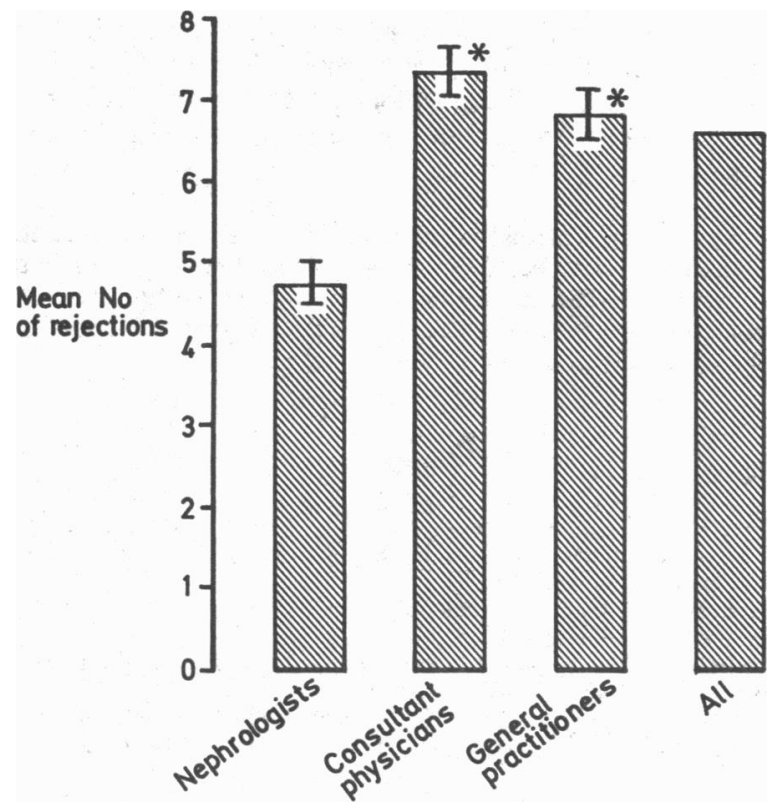

FIG 3-Mean numbers of cases rejected (out of 16) by types of doctors. Bars are SDs.

*Compared with nephrologists $\mathrm{p}<0.001$.

TABLE III-Percentages of various types of doctor rejecting each of the 16 patients. (Numbers in parentheses are ranking of cases (from 1 to 16) for rejection)

\begin{tabular}{|c|c|c|c|c|}
\hline $\begin{array}{l}\text { Case } \\
\text { No }\end{array}$ & Description of patient & Nephrologists & $\begin{array}{l}\text { Consultant } \\
\text { physicians }\end{array}$ & $\begin{array}{c}\text { General } \\
\text { practitioners }\end{array}$ \\
\hline $\begin{array}{l}1 \\
2 \\
3\end{array}$ & $\begin{array}{l}55 \text { year old woman with asthma } \\
72 \text { year old male vet } \\
36 \text { year old man with }\end{array}$ & $\begin{array}{l}1 \cdot 1(1) \\
4 \cdot 4(2)\end{array}$ & $\begin{array}{r}9 \cdot 2(1) \\
18 \cdot 4(2)\end{array}$ & $\begin{array}{l}10 \cdot 7(1) \\
19 \cdot 1(2)\end{array}$ \\
\hline $\begin{array}{l}4 \\
5 \\
6 \\
7 \\
8\end{array}$ & $\begin{array}{l}\text { paraplegia } \\
53 \text { year old male diabetic } \\
59 \text { year old female diabetic } \\
25 \text { year old blind male diabetic } \\
62 \text { year old man with stroke } \\
49 \text { year old woman with }\end{array}$ & $\begin{array}{c}7 \cdot 7(3) \\
9 \cdot 9(4) \\
16 \cdot 5(5=) \\
16 \cdot 5(5=) \\
20 \cdot 9(7)\end{array}$ & $\begin{array}{l}18.9(3) \\
23.2(4) \\
41 \cdot 1(9) \\
28 \cdot 7(5) \\
50 \cdot 3(10)\end{array}$ & $\begin{array}{l}26 \cdot 5(5) \\
37 \cdot 7(8) \\
41.9(9) \\
23 \cdot 3(4) \\
45 \cdot 1(10)\end{array}$ \\
\hline 9 & $\begin{array}{l}\text { rheumatoid arthritis } \\
50 \text { year old educationally }\end{array}$ & $22 \cdot 0(8)$ & $31 \cdot 9(7)$ & $28 \cdot 4(6)$ \\
\hline 10 & $\begin{array}{l}\text { subnormal woman } \\
45 \text { year old female analgesic }\end{array}$ & $23 \cdot 1(9)$ & $40.5(8)$ & $36 \cdot 3(7)$ \\
\hline 11 & $\begin{array}{l}\text { abuser } \\
67 \text { year old Asian with no }\end{array}$ & $25 \cdot 3(10)$ & $56 \cdot 8(11)$ & $54 \cdot 4(11)$ \\
\hline 12 & $\begin{array}{l}\text { English } \\
51 \text { year old woman with breast }\end{array}$ & $26 \cdot 4(11)$ & $30 \cdot 8(6)$ & $22 \cdot 3(3)$ \\
\hline 13 & $\begin{array}{l}\text { cancer } \\
50 \text { year old man with ischaemic }\end{array}$ & $27 \cdot 4(12)$ & $56 \cdot 8(12)$ & $65 \cdot 1(13)$ \\
\hline 14 & $\begin{array}{l}\text { heart disease } \\
30 \text { year old man with }\end{array}$ & $45 \cdot 1(13)$ & $89 \cdot 7(15)$ & $73.5(15)$ \\
\hline 15 & $\begin{array}{l}\text { schizophrenia } \\
52 \text { year old male alcoholic }\end{array}$ & $\begin{array}{l}58 \cdot 2(14) \\
79 \cdot 1(15)\end{array}$ & $\begin{array}{l}71 \cdot 9(13) \\
90 \cdot 3(16)\end{array}$ & $\begin{array}{l}56 \cdot 7(12) \\
80 \cdot 5(16)\end{array}$ \\
\hline & $\begin{array}{l}29 \text { year old nepatitis B positive } \\
\text { man }\end{array}$ & $86 \cdot 8(16)$ & $85 \cdot 4(14)$ & $71 \cdot 6(14)$ \\
\hline
\end{tabular}

A striking observation was that among all groups of doctors the two cases with the lowest rejection rates were the same-namely, the 55 year old asthmatic and the 72 year old vet. The subsequent pattern of selection was similar, with one notable exception: the 67 year old Asian with poor English was placed 11 th by nephrologists, sixth by consultant physicians, and third by general practitioners.

There was no relation between negative selection practice and year of graduation of responding doctor or regional provision level of renal services.

The overseas mailing generated a further 147 completed questionnaires, 19 from North America, 46 from eastern Europe, and 82 from western Europe. The mean rejection rates for North America and western Europe were 0.3 and 3.6 respectively, both lower than the 4.7 of the United Kingdom nephrologists. By contrast, the figure for the eastern European returns was $7 \cdot 5$, close to the $7 \cdot 4$ of United Kingdom consultant physicians.

\section{Discussion}

Various studies have produced figures for the incidence of end stage renal failure, ranging from $39 /$ million population $^{6}$ to $91 /$ million $^{7}$ in Western countries, depending on the age groups studied. In 1981, 26.7 new cases per million were accepted into dialysis and transplantation programmes in the United Kingdom compared with over 40 in many European countries (table I), a declared target for England and Wales of 50 by $1985,{ }^{8}$ and a rate in the United States in excess of 60 . If we assume that there are at least 60 new cases of treatable end stage renal failure per million population a year, then over 1500 patients die unnecessarily in this country each year. For every new patient accepted at least one goes untreated.

Although it is clear that inadequate facilities contribute to an acceptance rate that is low compared with other European countries, this is not the sole explanation. Few, if any, of the 61 renal units in the United Kingdom can claim to turn away as many as 25 patients a year. There is either a failure to detect or a failure to refer new cases, or both. The high age specific acceptance rate of young patients for dialysis and transplantation in this country suggests that the mechanism for detecting the disease is functioning effectively. There seems to be a breakdown in referral, and comparison with other countries (fig 1) shows that it is the patient aged over 45 or with multisystem disease ${ }^{8}$ who does not receive treatment.

This study was set up to investigate the question of underreferral and shows that in a hypothetical situation the mean rejection rate for treatment was significantly higher among general practitioners and consultant physicians than among nephrologists. The case histories were realistic; in the words of one responding nephrologist from the United States, "I think I could pull a parallel case for each and every one of them from our own treated population." Although we can say nothing about actual behaviour in the referral of patients for dialysis and transplantation, it is possible to draw conclusions about the knowledge of and attitude to current acceptance practice which influence behaviour.

The findings support the belief that underreferral of patients with end stage renal failure to renal units may contribute to the low acceptance rate for dialysis and transplantation in the United Kingdom, a shortfall that is particularly noticeable for those aged 45 and over. Given the very low age specific acceptance rate for patients aged 65 and over compared with other European countries, it is interesting that the 72 year old vet in this study should have been such a popular choice. That the pattern of rejection was broadly similar in the three groups of doctors suggests that the criteria applied to selection, whatever they were, were not just the result of specialist knowledge. This raises important moral and ethical questions about the way in which such decisions are made.

Although the responses from North America and Europe were not obtained in a systematic fashion, they provided interesting anecdotal evidence for the difference in approach to treatment of chronic renal failure, which a well provisioned dialysis sector permits. The mean rejection rate in North America from a mixture of nephrologists and general physicians was only 0.3 and in western Europe 3.6 , both much lower than the lowest British figure of $4 \cdot 7$ among nephrologists.

We received much correspondence from all the groups sampled, in which views and feelings were freely expressed. The volume of this correspondence bears witness to the interest evoked by the whole question of dialysis and transplantation. The letters also reinforced the evidence provided by statistical analyses for the role of underreferral in low acceptance rates in the United Kingdom. A sample of these comments are reproduced for the insight they afford. The first two came from 
North America and Europe and reflect a liberal acceptance policy based on adequate facilities:

I have answered your questionnaire with a resounding yes, yes, yes. . . . Nephrologist, USA.

Our criteria for exclusion are roughly the following:

-any accompanying disease probably leading to death within a short time (no more than a few months)

-over 80 years and poor clinical condition

-dementia.

Nephrologist, France.

Statements from the United Kingdom included the following from general practitioners:

One could easily answer by saying that none were suitable for treatment and indeed under present circumstances probably none would be accepted but given sufficient resources ideally most should be given a chance.

General Practitioner, UK.

I consider every person should be offered the opportunity to continue life, if that person so wishes.

General Practitioner, UK.

The following were received from United Kingdom consultant physicians and nephrologists:

I am not convinced that there is 'marked' under-provision of services for patients with [chronic renal failure] ... properly managed, terminal renal failure is not the worst way to die.

Consultant Physician, UK.

... we have no local nephrologist . . . we raised money for our own dialysis equipment but this was never purchased as the physicians decided that they did not want to be responsible for management of patients and equipment ... we have no real programme or plan to improve our facilities and I doubt whether we wish to develop one. Consultant Physician, UK.

... this form is irrelevant to my work.

Consultant Cardiologist, UK.

... I have no experience whatever in this field ... I do not ever have to consider patients for tr:atment of renal failure. ...

Consultant Geriatrician, UK.

... you will agree success or failure in dialysis so often depends on what the patient has between the ears. ...

Nephrologist, UK.

$\ldots$ one would rank on the positive side-ability to help the community by working; prospects of a successful transplant; and youth. On the debit side one would have to place difficulty in cooperating. ...

Consultant Physician, UK.

The only person really competent to judge the quality of life is the patient himself and one is very much aware that one's expectations in quality of life alter considerably with circumstances.

Consultant Physician, UK.

The results of the study were eloquently summarised in three letters, one from Europe, one from the United States, and one from the United Kingdom, which reflect the difference in referral practice for patients with end stage renal failure in the three areas:

Most GPs we are working with would probably ring us and ask our present opinion for each of the cases. The same would apply for hospital consultants whatever their personal feeling.

Nephrologist, Belgium.

... it is likely that almost all patients with end stage renal failure are seen by a nephrologist at some time in the course of their failure.

Nephrologist, USA.

... I worked at my local renal unit in a junior capacity some years ago .... I have always referred on merit and not based on what I know to be the facilities locally but I have made the value judgment as to who is meritorious myself. . . . The decision is mine rather than my local renal unit's ...

Consultant Physician, UK.
It appears that the practice of referral for specialist opinion in the United Kingdom is dramatically out of step with that in other countries. It is possible that this method of rationing applies in other developing forms of treatment.

These results support the view that underreferral of patients to renal units contributes to the low acceptance rate for dialysis and transplantation in the United Kingdom. It seems that many patients with end stage renal failure are being denied a nephrologist's opinion for various reasons. It will be of little value to change referral practice, however, unless there is a corresponding increase in nephrologists and renal replacement services to cope with 50 new patients per million population each year.

We express our thanks to all those doctors who completed the questionnaires, and especially to those who wrote to us. We also thank Sheila Dykes, Dina Shah, and Gwyneth Andrews without whose help this project would not have been possible. A grant to support this study has been given by the DHSS.

\section{References}

1 Kramer P, Brynger H, Brunner FP, et al. Combined report on regular dialysis and transplantation in Europe, XII, 1981. Proc Eur Dial Transplant Assoc 1982;19:3.

${ }^{2}$ McGeown MG. Chronic renal failure in N Ireland 1968-1970. A prospective study. Lancet $1972 ; \mathrm{i}: 307-10$.

${ }^{3}$ Pendreigh DM, Heasman MA, Howitt LF, et al. Survey of chronic renal failure in Scotland. Lancet $1972 ; \mathrm{i}: 304-7$

- Hiatt RA, Friedman GD. Characteristics of patients referred for treatment of end stage renal disease in a defined population. Am $\mathcal{F}$ Public Health 1982;72:829-33.

5 Wing AJ, Broyer M, Brunner FP, et al. Treatment of end stage renal failure in the United Kingdom: EDTA registry analyses. In: $U K$ Transplant Service reviezv. Southmead, Bristol: UK Transplant Service, 1982:33.

${ }^{6}$ Branch RA, Clark GW, Cochrane AL, et al. Incidence of uraemia and requirements for maintenance haemodialysis. $B r$ Med 71971 ; :249-54.

${ }^{7}$ Rostand SG, Kirk K, Rutsky E, Pate BA. Racial differences in the incidence of treatment for end stage renal disease. $N$ Engl f Med $1982 ; 306$ : 1276-9.

${ }^{*}$ Edwards N. Parliamentary written reply. House of Commons Official Report (Hansard) 1983 Dec 5;50:col 22 (No 63).

9 Jacobs C, Brunner FP, Brynger H, et al. The first five thousand diabetics treated by dialysis and transplantation in Europe. Diabetic Nephropathy $1983 ; 2: 12-6$.

${ }^{10}$ Challah S, Wing AJ. The epidemiology of genito-urinary disease. In: Holland WWH, Detels R, eds. Textbook of public health. Oxford: Oxford University Press. (In press.)

(Accepted 8 February 1984)

GENTIAN WATER COMPOUND-“Take of Gentian roots sliced, one pound and a half, the leaves and flowers of Centaury the less, of each four ounces, steep them eight days in twelve pounds of white Wine, then distil them in an alembick."

It conduces to preservation from ill air, and pestilential fevers: it opens obstructions of the liver, and helps such as they say are livergrown; it eases pains in the stomach, helps digestion, and eases such as have pains in their bones by ill lodging abroad in the cold, it provokes appetite, and is exceeding good for the yellow jaundice, as also for prickings or stitches in the sides: it provokes the menses, and expels both birth and placenta: it is naught for pregnant women. If there be no fever, you may take a spoonful by itself; if there be, you may, if you please, $\mathrm{mix}$ it with some cooler medicine appropriated to the same use you would give it for. (Nicholas Culpeper (1616-54) The Complete Herbal, 1850.)

BDELLIUM heats and mollifies, and that very temperately, being mixed with any convenient ointment or plaister, it helps kernels in the neck and throat, SCROPHULA, or that disease which was called the King's Evil. Inwardly taken in any convenient medicine, it provokes the menses, and breaks the stone, it helps coughs and bitings of venomous beasts: it helps windiness of the spleen, and pains in the sides thence coming. Both outwardly applied to the place and inwardly taken, it helps ruptures or such as are burst, it softens the hardness of the womb, dries up the moisture thereof and expels the dead child. (Nicholas Culpeper (1616-54) The Complete Herbal, 1850.) 